
\title{
Attitude of Young People in Small Towns and Metropolises towards Value-Statutory Regulation in the Runet at the Modern Mediatization Stage
}

\author{
Antonina Sibiriakova*, Irina Chudnovskaia and Olga Obryvalina \\ Lomonosov Moscow State University, Moscow, Russian Federation; a.a.sibiryakova@ya.ru
}

\begin{abstract}
The Internet as a new space of social-communicative interaction provides opportunities for new forms of the socio-statutory regulation. Territorial inequality of the mediatization process creates prerequisites for differentiation of preferences in the selection of the socio-communicative practices in the Internet. The purpose of this study is to determine the specific features of the attitude of young people in small towns and metropolises towards the value-statutory regulation in the Runet. On the basis of the qualitative study by an in-depth interview method, we obtained certain results about the similarities and differences in the socio-communicative practices and evaluations of the current value-statutory regulation in the Runet.
\end{abstract}

Keywords: Mediatization, Runet, Socio-Communicative Practices, Value-Statutory Regulation, Young People

\section{Introduction}

The modern state of society mediatization causes a range of social changes reflected in the socio-communicative practices and value systems. Offline- and online-spaces, which previously assumed differences in the socio-cultural behavior, are currently demonstrating their similarity. In these circumstances, the question arises: What will characterize the society's attitude towards regulation and control in the new media environment, which, in its turn, will directly determine its behavioral models?

A study of young people is of particular scientific interest, since, firstly, this social group is most active in the Internet; secondly, young people, due to their social and age peculiarities, tend to express a behavior deviating from the adopted norms, which mostly can be caused by the increased degree of freedom in the online space; thirdly, young people traditionally are a potential subject of the subsequent society stage and subsequent translator of socio-cultural values; fourthly, since mediatization and globalization processes imply internationalization, it is important whether young people preserve the peculiar features of our national culture or not. In this respect, it is important to understand whether any differences will appear in the attitude of young people in small towns and metropolises towards this issue due to differences at the level of mediatization and the Internet activity typical of such types of settlements.

Large sociological centers annually carry out researches in Russia and abroad, aimed at finding the public opinion in the area of the Internet space regulation ${ }^{1-5}$ including among residents of small towns in Russia ${ }^{6}$. In Russia, such researches are mostly conducted in large cities (over 100,000 people) using qualitative methods (they register the Internet access, media application frequency, etc.). Along with that, according to the Russian Federal State Statistics Service (Rosstat), currently there are 790 settlements in Russia with the total population of approximately 20 million people that are considered small towns ${ }^{7}$. At the same time, this issue requires a qualitative

\footnotetext{
${ }^{*}$ Author for correspondence
} 
approach disclosing the peculiarities of the routine socialcultural experience of the Internet users, including those in small towns.

The hypothesis of this study is as follows: Despite the existing differences at the level of the Internet penetration into metropolises and small towns, media-literacy and peculiar features of the Internet activity of young people living there, the behavior of the young people in the Internet, as well their attitude to the value-statutory regulation in the Runet will be similar. In particular, we suppose that young people will be skeptical to the existing measures of legal regulation and will prefer self-control as a primary mechanism of value-statutory regulation in the Internet space.

The issue of the Internet space regulation by different means (of legal, technical and value-statutory nature) is a relevant problem for each country, the solution of which has peculiar features predetermined by the geopolitical situation.

\section{Literature Review}

Problems of transformation of social norms and values in the Internet space, as well as of the security assurance in the network, at the current stage are disclosed in multiple publications of foreign researchers: Lessig ${ }^{8}$, Shea ${ }^{9}$, Shirky $^{10}$, Levin $^{11}$, Lyne $^{12}$, Patrizio ${ }^{13}$ et al. As for Russian researchers, such issues are studied by Bondarenko ${ }^{14}$, Zasurskii and Kozlovskii ${ }^{15}$, Tanimov and Kudashkin ${ }^{16}$, etc.

Research of media and further of the modern mediatization phenomena and its impact on the social processes and people, are disclosed in the works by Castells $^{17}$, Bolz ${ }^{18}$, Manovich ${ }^{19}$, Kolomietz ${ }^{20}$, Kirillova ${ }^{21}$, Savchuk $^{22}$, Sergeeva ${ }^{23}$, Chudnovskaia ${ }^{24}$, etc.

The works of these scientists comprised the methodological base for our research. Justification of the key theoretical points of the social-statutory regulation is also disclosed in our previous works ${ }^{25,26}$.

Studies of regulation of social relations in the online space form a rapidly developing interdisciplinary area. Along with that, at this stage, the need for a comprehensive sociological analysis of the studied problem in the context of the modern society mediatization still persists.

\section{Method}

Subject of research - value-statutory regulation in the Runet.
Scope of research - differences in the attitude of young people from small towns and metropolises towards valuestatutory regulation in the Runet.

Purpose of research - identification of the peculiar features of the attitude of young people in small towns and metropolises towards the value-statutory regulation in the Runet.

The subject, scope, purpose and hypothesis have determined the choice of the research strategy and method.

The research was conducted within the period from $17^{\text {th }}$ June until $20^{\text {th }}$ August, 2014 among young people in small towns of Rostov Oblast and inhabitants of a metropolis - the city of Moscow. It is assumed that small Russian towns have the population 50 thousand people or less, which, in its turn, distinguishes them from medium-sized (50 to 100 thousand people), large (100 to 250 thousand people) and other cities specified in the classification of the Urban Development Code of Russia ${ }^{27}$. Rostov Oblast (the Southern Federal District) was chosen for the comparison with Moscow with account of the fact that a significant number of active Internet users live there ${ }^{1}$ due to a high percentage of the Internet penetration at a relatively low price of access to the Internet.

Young people between 18 and 25 years of age were chosen as the empiric subject. It was decided to carry out a comparative analysis of the young people from the metropolis and small towns with a relatively equally high degree of the Internet activity, which provided a wider diversity of opinions, their informative value and justification and wider representativeness of the research results.

The research was conducted by the in-depth interview method, which allows to identify the behavior motives and thought patterns of each respondent, which is not always achievable for instance, in case of a focus-group.

The population of this research included young people from small towns and a metropolis of Russia aged between 18 and 25, where the decisive factor was the attainment by the respondents of the majority age enabling to expect reasonable answers to quite "adult" questions. The "snowball" method allowed creating a sample population of 40 respondents from the city of Moscow and three small towns of Rostov Oblast. The distribution of respondents by sex in the sample population corresponds proportionally to the gender representation in the overall population. The interview was arranged in small towns with the population of about 50 thousand. 
An approximate interview scenario had been developed in advance. Each respondent was interviewed for 30-50 minutes. At all stages of the in-depth interview, general instructions and requirements to such research methods were observed. The results were processed by mainly a comparative analysis, which suggests identification, comparison and interpretation of the respondents' polar opinions.

A structurally held interview is represented by a number of conceptual modules. The first module included acquaintance with the respondent and discovering his/ her age, education, marital status, children existence and frequency of the Internet use. The second module determined the level of the Internet penetration into small towns and metropolises, as well as the Internet activity of their citizens. The third module aimed at identification of the awareness level of the citizens of small towns and metropolises about the existence of Internet threats for children and other users in the online space and their attitude towards these issues. The fourth module of questions allowed determining the respondents' awareness of legal and technical measures of state regulation in the Runet and their attitude towards them. The fifth module disclosed the respondents' awareness in the area of informal social-statutory regulation and self-control in the Runet and identified the respondents' attitude towards such measures. Finally, the sixth module aimed at disclosing the respondents' propensity for (non-) normative behavior in the Internet.

\section{Results}

- We noted the similarity of socio-communicative practices of the Internet users in small towns and the metropolis.

- We revealed the different functional application of the Internet by young people: the metropolis inhabitants used the Internet opportunities to a maximum, while in small towns the social, household and entertaining use of the Internet prevailed. The different attitude of the inhabitants of the metropolis and small towns towards new "person-media" interaction practices (for example. "media-asceticism") was noted.

- Despite the different level of awareness about the modern state of the Internet, young people from the metropolis and small towns demonstrate similar views in relation to the value-statutory regulation in the Runet: they support the existing statutory regulation, but are skeptical towards its effectiveness; have a limited knowledge about non-state social control; obviously prefer self-control measures in respect of the Runet regulation, which is determined by the socio-cultural peculiar features of the Russian society.

- Young people from metropolis and small towns preferred identical models of online and offline communication, basing their interpersonal interactions on the moral norms typical of the Russian cultural traditions.

- Identical neutral attitude of the young people from the metropolis and small towns towards Internet piracy was discovered, which is confirmed by regular use of non-licensed production by the respondents.

- Against the background of general indifference of the young people in small towns and the metropolis to the process of the Internet de-anonymization, a significant number of young people in the metropolis expressed a desire to have a certain portion of freedom, which is indicative of their higher liberality in contrast to the young people in small towns.

\section{Discussion}

Today, the Internet increasingly penetrates into small towns, which is confirmed by a series of sociological studies (in 2014, 40\% of the Internet users lived in small towns and settlements) ${ }^{6}$. Nevertheless, the scale of Internet penetration into small towns has not achieved the metropolis' level yet, which is demonstrated by the lack of Wi-Fi zones in small towns, higher prices for the Internet services of the monopolist providers. According to the Ministry of Communications and Media of the Russian Federation, as of 2014, 1,343 settlements in Russia with the population between 500 and 10,000 had no access to the Internet ${ }^{28}$.

Citizens of small towns, young people in particular, actively master opportunities of the Internet. New resources allowing to effectively solve social and household issues remotely (online purchases, payment of bills, etc.) are especially popular, which is determined both by the deficiency of goods and services and by complicated appeal to some offline organizations. The Internet activity formats used by young people in Moscow and small towns become more similar. It is expressed in the daily use of the Internet by representatives of both types of settlements, almost identical preferences of the 
Internet access devices, active use of mobile access to the Internet, applications and online games, and which is not the least important, the media literacy level, which is sufficient enough for safe surfing.

Nevertheless, the gap still persists between the use of cultural and educational Internet opportunities, which are frequently ignored by young people in small towns, as they mostly focus on the Internet use for entertainment (watching movies, downloading music, communicating with friends, browsing news in social media, playing online games and more rarely, reading books) and information search for their own needs (searching for necessary (preparation for classes) or interesting (hobby) information). Some respondents noted that they used the Internet just to waste time. This can cause some bewilderment, since in settlements that lack social and cultural public places, young people have to compensate this deficiency by means of the Internet. However, according to the research, young people in small towns have low cultural and educational demands, which can be partially explained by the specific nature of their social environment. Young people in Moscow who live in a much more diverse social environment, characterized by a huge information and events flow, use all possible Internet opportunities to a maximum extent, expressing a significant interest in self-education and cultural development (webinars, useful applications, intellectual games, etc.). All this forms personal experience of Moscow respondents and explains their relatively higher awareness, interest and reflection in the issues of socialstatutory regulation in the Runet, than those of the young people in small towns. The impact of the position of the young people in Moscow is also produced by the diversity of media environment of the metropolis, which forms not only a life style but also a thinking pattern. Due to this, for example, the practice of media-asceticism is quite familiar to a large portion of young Muscovites and can be absolutely alien for the young people in small towns who are not fed up with the advanced media technologies.

The research has discovered obviously higher awareness of the young people in the metropolis about Internet threats (in contrast to the young people in small towns). Along with that, the perception and evaluation of the value-statutory regulation measures in the Internet space among young people in small towns and the metropolis almost always coincide. Thus, for example, citizens of both settlement types support measures of legal regulation in the Internet space in general. The obtained results for 2014 conform to the results of the quantitative research conducted in 2015 within the framework of the international project implemented by the Center of Global Communications Studies jointly with the All-Russian Public Opinion Research Center (VTSIOM), the purpose of which was to examine attitudes of Russian citizens towards Internet regulation (49\% of Russian citizens believe that the information content in the Internet needs being censored) $)^{2}$.

Nevertheless, our research discovered certain skepticism expressed by the representatives of both types of settlements in respect of such measures' effectiveness. Along with that, young people in the metropolis specified the problems of free speech restriction, laws development without consideration of citizens' opinions and a threat of total control over Internet users. Practically, the single example of relations regulation in the Internet without state interference, provided by the majority of young people in both settlement types, was the website moderation. This circumstance demonstrates certain limitation of knowledge of the Russian young people about the possibilities of non-state public control and speaks of incompleteness of the civil society establishment in Russia.

Young people in Moscow believe that beside state laws and technical programs, regulation of user behavior in the Internet must be performed by self-control measures. This point of view is also supported by more than half of the respondents in the small towns. Thus, one of them noted: "with our population and our large territories, it is extremely difficult to press on people, adopt laws and expect that they will immediately start working, especially since they are developed quite one-sidedly and frequently contain many controversies and amendments". Obvious preference of self-control measures by the majority of young people in small towns in the issues of the Runet regulation is determined by the general socio-cultural specificity of the Russian society. Traditionally, the issue of justice in the Russian culture has never been solved by law, since the latter was characterized by extreme selectiveness. (There are popular sayings: "One law for the rich and another for the poor", "Even if you go to a court, you cannot find justice there", "I don't care about laws since I know judges well"). In such circumstances, normative behavior of a person has neem provided by public control and non-written moral and religious norms determined by the highest values of the Russian culture and promoting conscience as the primary mechanism of social regulation.

The research also revealed lesser internationalization 
of the socio-communicative behavior patterns of the small towns' representatives in contrast to the metropolis citizens. It is expressed in their adherence to traditions and the social-cultural code. The belief of a part of respondents in small towns in the fact that the society control is a prerogative of the state can be associated with the socio-cultural code of the original patriarchal Russia ${ }^{25}$.

Almost absolute majority of the in-depth interview participants said that they did not change their communication model when entered the Internet space and adhered to the general moral norms in the process of communication with other users. Some respondents in Moscow noted that, along with the self-control in the Internet communications, they paid attention to the discipline of the work process organization in the Internet. As for open conflicts in Internet forums, young people from both sides mostly treat them neutrally, indicating that in case a dispute excludes offense, it can be interesting and even constructive. However, representatives of small towns mostly adhere to observers than to participants of such conflicts, which is not the case for Moscow representatives. A negative attitude to such conflicts was discovered among one third of small towns' representatives.

One of the most discussed problems of information distribution via Internet is the one which, in particular, induced development of the Internet space regulation measures - the copyright protection. Young people in Moscow and small towns have the idea what Internet piracy is; they treat it loyally and regularly use nonlicensed products. A respondent from a small town explained his opinion in the following way: "I object the anti-piracy law, since now I can't download any books and we don't have any proper bookstores here. We need to go to Rostov or order books via the Internet". Arguments of young people in Moscow include were: "Those who can afford it will buy it anyway and those who can't will find a way to steal," "I'm so used to downloading all I need from the Internet that a lack of such an opportunity causes rage more than understanding." It should be noted that most respondents in small towns and the metropolis neutrally treat Internet piracy and do not consider counteracting it as necessary (which can be explained both by insufficient awareness of what Internet piracy is and by its intentional exclusion from the controlled spheres).

A larger portion of respondents in small towns and the metropolis expressed indifference about possible cancellation of anonymity in the Internet and stated that they had nothing to conceal and this would have no effect on their behavior in the Internet. A significant portion of young people in Moscow expressed their compromise opinion supporting partial cancellation of anonymity due to the necessity to ensure certain freedom of actions to Internet users. Almost absolute majority of respondents in Moscow and small towns supported the draft law "On the Right to be Forgotten" and stated that, in case of necessity, they would use this right definitely.

Along with that, a specific difference from the perception of socio-statutory regulation of the Russianspeaking Web between the representatives of Moscow and small towns was slightly higher liberality of the young people from the metropolis (the focus was made on the necessity to provide freedom of action to Internet users) and conservatism of the inhabitants of small towns (some respondents supported totalitarian state control of the Runet). However, these differences do not affect the general normative behavior of young people in the metropolis and small towns online. Most respondents supported the idea of the Internet space regulation, voted against an open access of underage people to websites with offensive information and strongly believed that it was necessary to behave oneself in the Internet in strict compliance with the publicly adopted norms and rely on the self-control principles.

Thus, we can state that the research hypothesis in general has been confirmed.

\section{Conclusion}

Despite the differences in the degree of awareness, medialiteracy and Internet activity, principal commonness of attitudes of the young people in small towns and the metropolis towards the value-statutory regulation in the Runet was registered. When going online, young people do not change radically their socio-cultural behavioral models, typical of them when they are offline.

Young people, being the most flexible and amenable to social changes age group, are expected to master the opportunities of the new Internet environment more quickly. Anonymity as one of the characteristics of the Web allows extending the borders of online behavior to the maximum extent. However, as the conducted research shows, modern Russian young people continue to rely on the mechanisms of value-statutory regulation, which are characteristic for the offline mode. Under general support of complex regulation, young people prefer self-control. 
This can be explained both by technological factors (avalanche-type mediatization in Russia in contrast to Western countries) and by the socio-cultural peculiarities of the Russian society (importance of traditions).

The obtained results can be applied in the process of modernization of the Internet space regulation strategy.

\section{References}

1. Internet v Rossii. Zima 2011 [Internet in Russia. Winter 2011]. Byulleten Fonda «Obshchestvennoe mneniye» [Bulletin of the foundation "Obshchestvennoe Mnenie"]. 2011; 40. Available from: http://runet.fom.ru/uploads/files/Бюллетень_Интернет_в_России.Выпуск_40.3има_20122013_демо.pdf [in Russian].

2. Nisbet E. Chego zhelaet obshchestvo: stremlenie rossiyan $\mathrm{k}$ kontrolyu interneta [What the society wants: Eagerness of the Russian people for the Internet Control]. Official website of the Fund "Obshchestvennoe mneniye". 2015; Available from: http://www.wciom.ru/fileadmin/file/reports_ conferences/2015/2015-08-03_internet.pdf [in Russian].

3. Ekonomika Runeta. Issledovaniye ekonomiki rynkov internet-servisov i kontenta v Rossii v 2013-2014. Chego zhelaet obshchestvo: stremlenie rossiyan $\mathrm{k}$ kontrolyu interneta». Sotsiologicheskoe issledovaniye VTsIOM [Runet economy. Research of economies of the Internet services markets and Internet content in Russia in 2013-2014. What the Society Wants: Eagerness of the Russian People for the Internet Control". Sociological Study of VTSIOM]. Official website of the project "Research "Runet economy". 2015; Available from: http://экономикарунета.pф/upload/2014/ research-economics-2013-2014.pdf [in Russian].

4. Dutton $\mathrm{WH}$ et al. Cultures of the Internet: The Internet in Britain. Oxford Internet Survey 2013 Report. Oxford Internet Institute, University of Oxford. 2013; Available from: http://oxis.oii.ox.ac.uk/wp-content/uploads/ sites/43/2014/11/OxIS-2013.pdf

5. Global report on the cost of cyber crime: Sponsored by HP enterprise security. Independently conducted by Ponemon Institute. 2014; Available from: http://h20195.www2. hp.com/v2/getpdf.aspx/4AA5-5207ENW.pdf?ver=1.0

6. Dengi i internet: evoliutsiya povedeniya potrebiteley $\mathrm{v}$ malykh gorodakh. Rezultaty oprosa, provedennogo sredi rossiyskikh polzovateley interneta [Money and the Internet: Evolution of consumers' behavior in the small towns. Results of survey conducted among Russian Internet users. PayPal \& Data Insight]. April 2015; Available from: http:// www.slideshare.net/Data_Insight/ss-47288225 [in Russian].

7. Gruppirovka chisla gorodov po chislennosti naseleniya, prozhivayushchego $\mathrm{v}$ nikh, na 1 ianvaria 2015 goda. [Grouping of the number of towns According to their population as of $1^{\text {st }}$ January, 2015]. Federal State Statistics Service. 2015; Available from: http://www.gks.ru [in Russian].

8. Lessig L. Code: And other laws of cyberspace. Version 2.0.
New York: Basic Books; 2006.

9. Shea V. Netiquette. San Francisco: Albion Books; 1994.

10. Shirky C. Cognitive surplus: Creativity and generosity in a connected age. New York: The Penguin press; 2010.

11. Levin DB. Building social norms on the Internet. Yale Law School Legal Scholarship Repository; 2002.

12. Lyne J. Everyday cybercrime and what you can do about it. 2014; Available from: http://www.ted.com/talks/james_ lyne_everyday_cybercrime_and_what_you_can_do_ about_it\#t-1026975

13. Patrizio A. 12 surprising ways personal technology betrays your privacy. IT world. Oct 3, 2014; Available from: http://www.computerworld.com.au/slideshow/556469/ pictures-12-surprising-ways-personal-technology-betrays-your-privacy/

14. Bondarenko SV. Sotsialnaya struktura virtualnykh setevykh soobshchestv [Social structure of the virtual web communities]. Rostov-on-Don: Publishing House of the Rostov University; 2004. [in Russian].

15. Zasurskii I, Kharitonov V, Kozlovskii V, Alekseeva A. Avtorskie prava v internete. Perspektivy sistemy avtorskogo prava i podderzhka obshchestvennogo dostoianiya [Copyright in the Internet. Prospects of the copyright system and public domain support]. Moscow: Association of the Internet Publishers, Faculty of Journalism of the MSU; 2012. [in Russian].

16. Tanimov OV, Kudashkin YV. Perspektivy pravovogo regulirovaniya otnoshenii v seti Internet [Prospects of statutory regulation of relations in the Internet]. 2010; Available from: http://www.juristlib.ru/book_8682.htm [in Russian].

17. Castells M. Galaktika internet [Internet Galaxy]. Ekaterinburg; 2004.

18. Bolz N. Azbuka media [Media ABC]. Moscow; 2011 [in Russian].

19. Manovich L. the language of new media. Available from: http://manovich.net/LNM/Manovich.pdf

20. Kolomiets VP. Mediasotsiologiya: teoriya i praktika [Mediasociology: Theory and Practice]. Moscow: NIPKTS "Voskhod-A"; 2014. [in Russian].

21. Kirillova NB. Mediasreda rossiiskoy modernizatsii [Media environment of the Russian modernization]. Moscow: Akademicheskii proekt; 2005. [in Russian].

22. Savchuk VV. Mediafilosofiya: formirovaniye distsipliny. Mediafilosofiya: osnovnye problemy i poniatiya [Media-philosophy: Discipline formation. Media-Philosophy: Main Problems and Concepts]. Savchuk VV (Editor). St Petersburg; 2008, [in Russian].

23. Sergeyeva OV. Mediakultura $v$ praktikakh povsednevnosti [Mediaculture in Daily Practices] [PhD thesis]. St. Petersburg; 2011. [in Russian].

24. Chudnovskaya IN, Chudnovskiy, LS. Individ $\mathrm{v}$ informatsionno-kommunikativnom prostranstve: Mnogourovnevaya model funktsionirovaniya [Individual in the information-communication space: Multilevel model of functioning]. LAP LAMBERT Academic Publishing, Saarbrücken; 2011. [in Russian]. 
25. Baklantseva AA. Osobennosti postroeniya sotsionormativnoy sistemy reguliatsii obshchestva v sovremennoy Rossii [Peculiarities of structure of the social-statutory system of society regulation in modern Russia]. Sotsiologiia. Sociology. 2014; 3:3-10. [in Russian].

26. Obryvalina OA. Kontseptsii sotsialnogo kontrolya v amerikanskoy sotsiologii kontsa XIX-XX vekov: istoriko-sotsiologicheskiy analiz [Concepts of social control in the American Sociology of the Late 19-20 Centuries: Histori-
cal-Sociological Analysis] [PhD thesis].Moscow; 2014. [in Russian].

27. Urban Development Code of Russia dated 07.05.1998 \#73FZ. 1998; Available from: http://www.consultant.ru/popular/gskrf/ [in Russian].

28. Official website of the Ministry of Communications and Media of Russia. Available from: http://minsvyaz.ru/ru/ [in Russian]. 